\title{
Discoloration of the mucosa caused by different restorative materials - a spectrophotometric in vitro study
}

Ioannidis, Alexis ; Cathomen, Elena ; Jung, Ronald E ; Fehmer, Vincent ; Hüsler, Jürg ; Thoma, Daniel S

\begin{abstract}
OBJECTIVES To evaluate the discoloration of the mucosa caused by different ceramic and metal-based materials. MATERIAL AND METHODS On six pig maxillae, trap-door flaps were prepared bilaterally. Different ceramic and metal-based specimens were placed underneath the flap. To simulate increasing mucosal thicknesses (MC), connective tissue grafts (CTGs) were harvested. Spectrophotometric measurements were performed prior to flap elevation (TBL ) and for each material under the flap alone (1 mm MC) (TMC1 ), with a 1-mm CTG (2mm MC) (TMC2 ) and with a 2-mm CTG (3-mm MC) (TMC3 ). Tested materials were as follows: Zr1 (zirconia), Zr2 (zirconia + pink ceramic), Zr3 (zirconia), Zr4 (fluorescent zirconia), Zr5 (zirconia), Zr6 (high translucent zirconia), Zr7 (low translucent zirconia) and Zr8 (low translucent zirconia), Gol (gold alloy), Ti1 (titanium alloy), Ti2 (anodized gold-shaded titanium alloy) and Ti3 (anodized pink-shaded titanium alloy). Color differences $(\Delta \mathrm{E})$ were calculated comparing the measurement of the native tissue (TBL ) and the measurements with varying mucosal thicknesses (TMC1-3 ). RESULTS For ceramic materials, the median $\triangle \mathrm{E}$ values for the different timepoint comparison ranged as follows: 3.80 (Zr4) - 7.47 (Zr2) (pooled); 3.15 (Zr4) - 8.13 (Zr2) (TBL -TMC1 ); 3.39 (Zr4) - 7.24 (Zr2) (TBL -TMC2 ); 4.31 (Zr8) - 6.99 (Zr2) (TBL -TMC3 ). For metal-based materials, the median $\triangle \mathrm{E}$ values were as follows: $4.20(\mathrm{Gol})$ - 5.82 (Ti3) (pooled); 3.21 (Gol) - 13.56 (Ti1) (TBL -TCM1 ); 4.0 (Ti1) 5.27 (Gol) (TBL -TCM2 ); 3.11 (Ti1) - 5.11 (Gol) (TBL -TCM2 ). The comparison of the materials and the time points showed in the nonparametric linear mixed model a significant interaction effect between material and time point $(\mathrm{P}<0.001)$. The side was not a significant main effect, nor as term in an interaction with the other two effects. CONCLUSIONS Reconstructive materials result in an evident discoloration of the mucosal tissue, tending to decrease with increasing mucosal thickness. The use of fluorescent zirconia (ceramic materials) or gold alloy (metal-based materials) lead to the least discoloration.
\end{abstract}

DOI: https://doi.org/10.1111/clr.12928

Posted at the Zurich Open Repository and Archive, University of Zurich ZORA URL: https://doi.org/10.5167/uzh-126621

Journal Article

Accepted Version

Originally published at:

Ioannidis, Alexis; Cathomen, Elena; Jung, Ronald E; Fehmer, Vincent; Hüsler, Jürg; Thoma, Daniel S (2017). Discoloration of the mucosa caused by different restorative materials - a spectrophotometric in vitro study. Clinical Oral Implants Research, 28(9):1133-1138.

DOI: https://doi.org/10.1111/clr.12928 


\section{Discoloration of the mucosa caused by different restorative}

\section{materials - a spectrophotometric in vitro study}

\section{Running head: Mucosal discoloration caused by restorative materials}

Dr. med. dent. Alexis loannidis ${ }^{1 *}$, cand. med. dent. Elena Cathomen ${ }^{2}$, Prof. Dr. med. dent. Ronald E. Jung ${ }^{1}$, MDT Vincent Fehmer ${ }^{3}$, Prof. em. Dr. phil. nat. Jürg Hüsler ${ }^{4}$, PD Dr. med. dent. Daniel S. Thoma ${ }^{1}\left({ }^{*}\right.$ equally contributing authors)

Key words: color, spectrophotometer, abutment, dental implant, ceramic, metal

Address for correspondence:

PD Dr. Daniel S. Thoma

Clinic of Fixed and Removable Prosthodontics and

Dental Material Science

Center of Dental Medicine, University of Zurich

Plattenstrasse 11

$\mathrm{CH}-8032$ Zurich, Switzerland

Phone: +41446343260

Fax: +41446344305

E-mail: daniel.thoma@zzm.uzh.ch

${ }^{1}$ Clinic for Fixed and Removable Prosthodontics and Dental Material Science, Center of Dental Medicine, University of Zurich, Zurich, Switzerland

${ }^{2}$ Pre-doc student, Center of Dental Medicine, University of Zurich, Zurich, Switzerland

${ }^{3}$ Division of Fixed Prosthodontics and Biomaterials, Center of Dental Medicine, University of Geneva, Geneva, Switzerland

${ }^{4}$ Institute of Mathematical Statistics and Actuarial Science, University of Berne, Berne, Switzerland. 


\section{Abstract}

Objectives: To evaluate the discoloration of the mucosa caused by different ceramic and metal-based materials.

Material and methods: On six pig maxillae, trap door flaps were prepared bilaterally. Different ceramic and metal-based specimens were placed underneath the flap. In order to simulate increasing mucosal thicknesses (MC) connective tissue grafts (CTGs) were harvested. Spectrophotometric measurements were performed prior to flap elevation ( $\left.T_{B L}\right)$ and for each material under the flap alone $(1 \mathrm{~mm} \mathrm{MC})\left(\mathrm{T}_{\mathrm{MC} 1}\right)$, with a $1 \mathrm{~mm} C \mathrm{CTG}(2 \mathrm{~mm} \mathrm{MC})$ ( $\left.\mathrm{T}_{\mathrm{MC} 2}\right)$ and with a $2 \mathrm{~mm}$ CTG (3 mm MC) $\left(\mathrm{T}_{\mathrm{MC} 3}\right)$. Tested materials were: $\mathrm{Zr}$ 1 (zirconia), Zr2 (zirconia + pink ceramic), Zr3 (zirconia), Zr4 (fluorescent zirconia), Zr5 (zirconia), Zr6 (high translucent zirconia), Zr7 (low translucent zirconia) and Zr8 (low translucent zirconia), Gol (gold alloy), Ti1 (titanium alloy), Ti2 (anodized gold-shaded titanium alloy) and Ti3 (anodized pink-shaded titanium alloy). Color differences $(\Delta \mathrm{E})$ were calculated comparing the measurement of the native tissue $\left(\mathrm{T}_{\mathrm{BL}}\right)$ and the measurements with varying mucosal thicknesses $\left(\mathrm{T}_{\mathrm{MC1} 1-3}\right)$.

Results: For ceramic materials, the median $\Delta \mathrm{E}$ values for the different time-point comparison ranged as follows: $3.80(\mathrm{Zr} 4)-7.47(\mathrm{Zr} 2)$ (pooled); $3.15(\mathrm{Zr} 4)-8.13(\mathrm{Zr} 2)\left(\mathrm{T}_{\mathrm{BL}}{ }^{-}\right.$ $\left.\mathrm{T}_{\mathrm{MC} 1}\right)$; 3.39 ( $\left.\mathrm{Zr} 4\right)$ - $7.24(\mathrm{Zr} 2)\left(\mathrm{T}_{\mathrm{BL}}-\mathrm{T}_{\mathrm{MC} 2}\right) ; 4.31$ (Zr8) - $6.99(\mathrm{Zr} 2)\left(\mathrm{T}_{\mathrm{BL}}-\mathrm{T}_{\mathrm{MC} 3}\right)$. For metal-based materials, the median $\Delta \mathrm{E}$ values were: 4.20 (Gol) - 5.82 (Ti3) (pooled); 3.21 (Gol) - 13.56 (Ti1) $\left(\mathrm{T}_{\mathrm{BL}}-\mathrm{T}_{\mathrm{CM} 1}\right) ; 4.0$ (Ti1) - 5.27 (Gol) $\left(\mathrm{T}_{\mathrm{BL}}-\mathrm{T}_{\mathrm{CM} 2}\right) ; 3.11$ (Ti1) - 5.11 (Gol) $\left(\mathrm{T}_{\mathrm{BL}}-\mathrm{T}_{\mathrm{CM} 2}\right)$. The comparison of the materials and the time points showed in the nonparametric linear mixed model a significant interaction effect between material and time-point $(p<0.001)$. The side was not a significant main effect, nor as term in an interaction with the other two effects. 
Conclusions: Reconstructive materials result in an evident discoloration of the mucosal tissue, tending to decrease with increasing mucosal thickness. The use of fluorescent zirconia (ceramic materials) or gold alloy (metal-based materials) lead to the least discoloration. 


\section{Introduction}

A large variety of reconstructive materials are available for implant-borne reconstructions (Fehmer, et al. 2014). The spectrum of materials ranges from metals, ceramics to resins. These materials, being used for abutments, reconstructions and as part of the implant body, usually emerge through the mucosa to the oral cavity and consequently influence the color of the peri-implant tissues (Thoma, et al. 2016).

The esthetics demands of patients gained more and more attention in recent years. Thus, it is the goal to optimize esthetic outcomes and to avoid a discoloration of the marginal area of the mucosa around implant-borne reconstructions. Studies indicate that color differences of the human gingiva or human mucosa are visible by naked eye in case $\Delta \mathrm{E}$ values are above 3.1 (Sailer, et al. 2014). Titanium is known as the gold standard for implant-shoulder and abutment materials. Based on a series of in vitro and clinical studies, titanium leads to a grayish discoloration of the peri-implant tissue (Heydecke, et al. 1999, Jung, et al. 2008, Thoma, et al. 2016). In order to overcome these esthetic issues, ceramic materials were evaluated (Bressan, et al. 2011, Happe, et al. 2013b, Jung, et al. 2008, Jung, et al. 2007, Kim, et al. 2015, Linkevicius \& Vaitelis 2015). Ceramics offer esthetic benefits, but still induce a visible discoloration of the mucosa depending on the soft tissue thickness (Jung, et al. 2008, Linkevicius \& Vaitelis 2015, Thoma, et al. 2016). Moreover, the postulated threshold values to detect color differences appears to be $2 \mathrm{~mm}$ of mucosal thickness (Jung, et al. 2007).

Several modifications of existing ceramic and metal-based materials are marketed. By modifying metal-based materials or by choosing appropriate ceramic materials, the colorimetric outcomes may be improved. Alterations of metal-based materials were investigated in several clinical studies, containing the color modification of titanium by using 
different gold or gingiva-colored hues (Claffey \& Shanley 1986, Kim, et al. 2015, Paul, et al. 2002, Sumi, et al. 2014). Ceramic materials can be modified by reducing the opacity, by increasing the fluorescence or by veneering with mucosa colored ceramic (Happe, et al. 2013b, Jung, et al. 2007). Today, the range of newly developed materials with different optical properties is wide. However, no screening method exists evaluating the discoloration potential of the respective materials under different mucosal conditions. Therefore, the aim of the present study was to evaluate the discoloration of the mucosa caused by different ceramic and metal-based materials depending on the soft tissue thickness. 


\section{Materials and Methods}

\section{Study design}

For the present in vitro investigation, 6 fresh pig maxillae were used within 4 hours of animal sacrifice. All animals were approximately 6-months of age and were farmed for food production according to the Swiss standards for animal care. This study was not classified as an animal study and the local ethical committee had no objection to this investigation. This in vitro animal model was selected because of its anatomy with partially edentulous sites and a mucosa, which resembles the human keratinized mucosa in color and texture.

\section{Test specimens}

Two groups of dental reconstructive materials were used in the present study: ceramic materials and metal-based materials. Some $\left({ }^{*}\right)$ of these materials are available as abutment materials for implant reconstructions, whereas others were of experimental design. Test specimens of the size $4 \times 4 \times 1.5 \mathrm{~mm}$ (length $\mathrm{x}$ width $\mathrm{x}$ depth) were produced for each material. All materials are shown in Figure 1. In detail, the following materials were tested:

Ceramic materials

- Zr1: Zirconia (e.max ZirCAD MO, Ivoclar Vivadent, Schaan, Liechtenstein) *

- Zr2: Zirconia veneered with pink ceramic (zirconia: e.max ZirCAD MO, Ivoclar Vivadent, Schaan, Liechtenstein / veneering ceramic: Creation G2 dark pink; Creation Willi Geller International $\mathrm{GmbH}$, Meiningen, Austria)

- Zr3: (Atlantis shade 020, Dentsply International Inc.; New York/New York, USA) 
- Zr4: Fluorescent zirconia (LAVA Plus High Translucency Zirconia, Lava Plus Effect Shade "Fluorescence", 3M ESPE; St. Paul/Minnesota, USA) *

- Zr5: Zirconia (Katana Noritake multilayered; Kuraray Europe GmbH, Hattersheim am Main, Deutschland) *

- Zr6: High translucent zirconia (Metoxit HTL; Metoxit; Thayngen, Switzerland) *

- Zr7: Low translucent zirconia (Metoxit TL; Metoxit; Thayngen, Switzerland) *

- Zr8: Low translucent zirconia (Metoxit Z-CAD; Metoxit; Thayngen, Switzerland) *

Metal-based materials

- Gol: Gold alloy (CM Protor 3; Cendres + Métaux, Biel, Switerzland)

- Ti1: Titanium alloy (TRI Dental Implants; Baar, Switzerland)

- Ti2: Anodized (gold-shaded) titanium alloy (TRI Dental Implants; Baar, Switzerland)

- Ti3: Anodized (pink-shaded) titanium alloy (TRI Dental Implants; Baar, Switzerland)

\section{Surgical protocol and spectrophotometric measurements}

The surgical protocol and the time-points of spectrophotometric measurements are displayed in Figure 2. The measurements were performed for each of the specimens separately.

At each side of the pig maxillae in the region disto-palatally to the last molar, incisions were made and a partial-thickness trap-door-type flap prepared with a thickness of $1 \mathrm{~mm}$ (Fig. 2). Spectrophotometric measurements (SpectroShade, No. LUA005, Medical High Technologies; software version 2.5, MHT) were performed at these sites and served as controls for the native mucosa $\left(\mathrm{T}_{\mathrm{BL}}\right)$. The specimens were placed underneath the trap-door partial thickness flap, before performing again a spectrophotometric measurement $\left(T_{M C 1}\right)$. 
Consecutively, two connective tissue grafts (CTG) were harvested from the palate of the pigs. Both CTGs had a final dimension of $8 \times 8 \mathrm{~mm}$ (width $\times$ length), but differed in thickness: $1 \mathrm{~mm}$ and $2 \mathrm{~mm}$. The thickness of the harvested CTGs was trimmed and consecutively controlled by means of a gauge.

Spectrophotometric analysis was performed again, after having placed the $1 \mathrm{~mm}$ thick CTG between the specimen and the flap $\left(\mathrm{T}_{\mathrm{MC} 2}\right)$. The procedure was repeated by placing the $2 \mathrm{~mm}$ thick CTG between the specimen and the retracted flap ( $\left.T_{M C 3}\right)$.

Whereas $T_{B L}$ served as control for the native mucosa, the three consecutive measurements were performed with a differing mucosal thickness above the specimens:

- $\quad \mathrm{T}_{\mathrm{MC1}}: 1 \mathrm{~mm}$ thick tissue (trap-door flap)

- $\quad \mathrm{T}_{\mathrm{MC2}}: 2 \mathrm{~mm}$ thick tissue (trap-door flap $+1 \mathrm{~mm} \mathrm{CTG)}$

- $\mathrm{T}_{\text {Mс3 }}: 3 \mathrm{~mm}$ thick tissue (trap-door flap $+2 \mathrm{~mm} \mathrm{CTG)}$

\section{Spectrophotometric analysis}

The colorimetric assessment performed in this study, was described in detail in a previous publication (Jung, et al. 2007). In brief, the colorimetric measurements were taken by means of a spectrophotometer (SpectroShade, No. LUA005, Medical High Technologies; software version 2.5, MHT). The spectrophotometer, which is capable to objectively evaluate the mucosal colors, contains of a disposable light-focusing cone to record the digital pictures. The captured image was transferred to the computer and the areas of interest were selected for spectrophotometric analysis. Analysis revealed data based on the indications of the Commission Internationale de l'Éclairage (CIE), with $\mathrm{L}=$ lightness, a = chroma along redgreen axis, and b = chroma along yellow-blue axis (Paul, et al. 2002). 
Three consecutive pictures of each area were taken perpendicular to the mucosa and used for data analysis. In the software of the spectrophotometer, a circular area of interest of 2 $\mathrm{mm}$ in diameter was chosen in which shade determination was performed. This disclosed CIE lab parameters for each picture. The three consecutive measurements were pooled and averaged.

Color differences $(\Delta \mathrm{E})$ were determined by using mean values of $\mathrm{L}, \mathrm{a}$ and $\mathrm{b}$ with the following equation: $\Delta E=\left(\Delta \mathrm{L}^{2}+\Delta \mathrm{a}^{2}+\mathrm{b}^{2}\right)^{1 / 2}$. Thereby, these differences were calculated by subtracting the baseline measurements $\left(T_{B L}\right)$ from the consecutive measurements with the specimens ( $\left.\mathrm{T}_{\mathrm{MC} 1}, \mathrm{~T}_{\mathrm{MC} 2}, \mathrm{~T}_{\mathrm{MC} 3}\right)$.

\section{Statistical analysis}

The data were coded in a software program (Microsoft Excel). The metric variables were described with mean, median, minimum and maximum, and standard deviation. For the comparison of the materials and the time points and the dependence of the data linear mixed models with the pig as random effect were applied. Because the residuals did not show normality, the rank based nonparametric approach was used. A p-value $<0.05$ indicates a significant result. 


\section{Results}

The descriptive data such as mean, standard deviation (SD), minimum, maximum and median of the $\Delta E$ values of the different comparisons ( $T_{B L}$ versus $T_{M C 1}, T_{B L}$ versus $T_{M C 2}, T_{B L}$ versus $\left.\mathrm{T}_{\mathrm{MC} 3}\right)$ are displayed in Table 1. In total, 36 measurements were performed per group. With the different time-point-comparisons $\left(T_{B L}-T_{M C 1}, T_{B L}-T_{M C 2}, T_{B L}-T_{M C 3}\right)$, this resulted in 12 measurements per time-point and material.

\section{Ceramic materials}

By pooling all measurements per material, the lowest median $\Delta \mathrm{E}$ value was calculated for $\mathrm{Zr} 4$ (3.80). Zr2 revealed the highest corresponding median $\Delta \mathrm{E}$ value (7.47). With a total tissue thickness of $1 \mathrm{~mm}\left(T_{B L}\right.$ versus $\left.T_{M C 1}\right)$, again, $\mathrm{Zr} 4$ showed the lowest median $\Delta E$ value (3.15) and $\mathrm{Zr2}$ revealed the highest (8.13). With a total tissue thickness of $2 \mathrm{~mm}$ above the specimen $\left(T_{B L}\right.$ versus $T_{M C 2}$ ), the lowest and highest median $\Delta E$ values were seen in the following groups: $\mathrm{Zr} 4$ (3.39) and $\mathrm{Zr} 2$ (7.24). The comparison $\mathrm{T}_{\mathrm{BL}}$ versus $\mathrm{T}_{\mathrm{MC}}$ (total tissue thickness of $3 \mathrm{~mm}$ ), exhibited the lowest median $\Delta \mathrm{E}$ value in the group $\mathrm{Zr}$ (4.31), while $\mathrm{Zr} 2$ (6.99) led to the highest median color difference. The group Zr2 (4.72) again reached a low median color change.

\section{Metal-based materials}

For the pooled time-point comparisons, Gol showed the lowest median $\Delta \mathrm{E}$ value (4.20), while Ti3 exhibited the highest (5.82). For the detailed analysis, split by time-points, again, Gol revealed the lowest median $\Delta \mathrm{E}$ value (3.21) for a total tissue thickness of $1 \mathrm{~mm}\left(\mathrm{~T}_{\mathrm{BL}}-\right.$ 
$T_{M C 1}$ ). Ti1 showed the highest corresponding median $\Delta E$ value (13.56) for this comparison $\left(T_{B L}-T_{M C 1}\right)$. With a total tissue thickness of $2 \mathrm{~mm} \quad\left(T_{B L}-T_{M C 2}\right)$, Ti1 revealed the lowest (4.00) and $\mathrm{Gol}$ reveled the highest median $\Delta \mathrm{E}$ value (5.27). For the comparison $\mathrm{T}_{\mathrm{BL}}-\mathrm{T}_{\mathrm{MC}}$ and $\mathrm{a}$ total tissue thickness of $3 \mathrm{~mm}$ above the tested material, Ti1 (3.11) and Gol (5.11) were the outliers.

Comparison of the materials and the time points

The comparison of the materials and the time points showed in the nonparametric linear mixed model a significant interaction effect between material and time-point $(p<0.001)$. The side was not a significant main effect, nor as term in an interaction with the other two effects. Hence the differences are best described by the values listed in the Table 1. 


\section{Discussion}

The present study spectrophotometrically evaluated the extent of discoloration of the mucosa caused by ceramic and metal-based reconstructive materials. The measurements were performed with differing mucosal thicknesses overlaying the tested materials. The study demonstrated that (1) the placement of ceramic and metal-based materials underneath the mucosa resulted in a varying discoloration above the clinically visible threshold value of 3.1 (Sailer et al. 2014), (2) the extent of discoloration tended to decrease with an increasing mucosal thickness, (3) the use of fluorescent zirconia ( $\mathrm{Zr} 4$, ceramic group) and gold alloy (Gol, metal-based group) resulted in the, esthetically, most favorable outcomes.

For ceramic materials, fluorescent zirconia $(\mathrm{Zr} 4)$ revealed the least discoloration - in general and with a $1 \mathrm{~mm}$ and $2 \mathrm{~mm}$ thin mucosa. Even with a thick mucosa of $3 \mathrm{~mm}$, this material demonstrated favorable results. An in-vitro study aiming to test the effect of dyed fluorescent zirconia on the color of a $1.5 \mathrm{~mm}$ thick pig mucosa, showed results in line with the present study. A mean $\Delta \mathrm{E}$ of 3.5 was calculated in comparison to the test area without underlying material (Happe, et al. 2013b). The same material was tested clinically in 12 patients against a natural gingival tissue (Happe, et al. 2013a). The spectrophotometric measurements were performed in five incremental areas relative to the mucosal margin. The median ranged from 4.12 (area $0-1 \mathrm{~mm}$ proximal to the mucosal margin) to 5.36 (area $4-5 \mathrm{~mm}$ away from the mucosal margin) (Happe, et al. 2013a). The higher $\Delta \mathrm{E}$ values might be due to an increasing soft tissue thickness in more apical regions. This corroborates findings from in vitro studies, demonstrating less discoloration with an increasing mucosal thickness (Jung, et al. 2007, Thoma, et al. 2016). In contrast, in the group with the fluorescent zirconia (Zr4) (present study), the grade of discoloration increased with increasing thickness of the mucosa. 
However, for all mucosal thicknesses the $\Delta \mathrm{E}$ values were barely higher than a in the literature reported $\Delta \mathrm{E}$ threshold value of 3.1 for the perceptibility of mucosal color changes (Sailer, et al. 2014)

In terms of metal-based materials, the results demonstrated that in case of a thin mucosa (1 $\mathrm{mm}$ thickness), the use of a gold alloy (Gol) was superior compared to titanium alloy materials (Ti1, Ti2, Ti3) and revealed comparable $\Delta \mathrm{E}$ values to the most favorable ceramic materials tested in this investigation. In a clinical study with 20 patients, the influence of the abutment material on the color of the peri-implant soft tissue was analyzed (Bressan, et al. 2011). The $\Delta \mathrm{E}$ values obtained with gold and zirconia abutments were comparable, whereas titanium abutments led to a significantly higher discoloration of the peri-implant soft tissue (Bressan, et al. 2011). In the present investigation, anodized gold- (Ti2) and pink-shaded (Ti3) titanium alloys were tested. Gold shading of titanium (Ti2) did not reduce $\Delta \mathrm{E}$ values compared to titanium alloy (Ti1), at least a gingival thickness of $1 \mathrm{~mm}$. In contrast, pink shading of titanium alloy (Ti3) showed more favorable $\Delta \mathrm{E}$ values than titanium alloy (Ti1) at the same gingival thickness $(1 \mathrm{~mm})$. This is in agreement with a clinical case series (Sumi, et al. 2014). Gingiva-colored abutments obtained by anodic oxidation provided improved esthetical outcomes, especially in cases with a thin mucosal biotype (Sumi, et al. 2014). At 2 and $3 \mathrm{~mm}$ of gingival thickness overlying the tested material, the differences in $\Delta \mathrm{E}$ values within the metal-based groups become negligible. Even the gold shading of the titanium alloy (Ti2), did not influence the amount of discoloration, irrespective of the mucosal thickness. This finding is in accordance with the results of a clinical study which did not find any statistically significant color differences between a gold-hued titanium abutment and a regular titanium abutment (Kim, et al. 2015). 
In this study, a pig model was used to detect differences between various ceramic and metal-based materials and their effect on the discoloration of the mucosa. This in vitro model allows testing reconstructive materials under strictly standardized conditions. This model has been verified in several studies and demonstrated to be suitable for testing mucosal color changes caused by different restorative materials (Happe, et al. 2013b, Jung, et al. 2007, Pecnik, et al. 2015, Thoma, et al. 2016). The gingival discoloration was measured by means of a spectrophotometer, based on the CIE color system. The reproducibility and the accuracy of spectrophotometric color analysis is known to be higher than visual shade assessment (Da Silva, et al. 2008, Jung, et al. 2007, Paul, et al. 2002). The use of this technique allows comparing results of different studies. Still, the translation of in vitro data into clinical settings is limited. This mainly relates to the use of animals (pig jaws) and, even though the jaws were obtained shortly before the experiment, the lack of a blood flow. Histologically, the mucosa of pigs and humans appears to have a similar composition (Cho, et al. 2013, Jung, et al. 2011). In contrast to humans, the harvested SCTG did not show any fatty tissue, but a dense connective tissue. Further clinical studies will be needed to reproduce the obtained data in a clinical environment applying the same technologies (spectrophotometry).

\section{Conclusions}

Within the limitations of this in vitro study, the following conclusions can be drawn:

- Ceramic and metal-based abutment and implant-shoulder materials underneath the periimplant mucosa resulted in a evident discoloration of the mucosal tissues

- The amount of discoloration tended to decrease with an increasing mucosal thickness 
- In the group of ceramic abutment materials, the use of fluorescent zirconia lead to the most favorable esthetic outcomes in terms of discoloration

- In the group of metal-based materials, a gold alloy as an abutment material or an anodized pink-shaded titanium alloy as a modification of the implant-shoulder leads, in cases of a thin peri-implant mucosal tissue, to the most promising results.

\section{Conflict of Interest}

This study was financially supported by the Clinic for Fixed and Removable Prosthodontics and Dental Material Science, Center of Dental Medicine, University of Zurich, Zurich, Switzerland and by TRI Dental Implants (Baar, Switzerland). Furthermore, materials were provided by Dentsply (York, PA, USA), 3M Espe (Seefeld, Germany) and TRI Dental Implants (Baar, Switzerland).

\section{Acknowledgements}

The author would like to thank Gisela Müller for helping to prepare the manuscript and Philippe Halioua for taking the pictures of the specimens. 


\section{Tables}

Table 1 - Descriptive data (mean \pm standard deviation, minimum, maximum and median) of the $\Delta \mathrm{E}$ values of the different comparisons pooled for all-comparisons and split by time-point comparison.

\begin{tabular}{|c|c|c|c|c|c|c|c|c|c|c|c|c|c|}
\hline & \multirow[b]{2}{*}{ Material } & \multicolumn{5}{|c|}{ pooled data for all comparisons } & \multicolumn{7}{|c|}{ split by time-point comparison } \\
\hline & & $n$ & mean \pm SD & minimum & maximum & median & comparison & $\begin{array}{l}\text { mucosal } \\
\text { thickness }\end{array}$ & $\mathbf{n}$ & mean \pm SD & minimum & maximum & median \\
\hline \multirow{24}{*}{ ceramic } & \multirow{3}{*}{$\begin{array}{l}\text { Zr1 } \\
\text { Zirconia (e.max ZirCAD MO, Ivoclar } \\
\text { Vivadent, Schaan, Liechtenstein) }\end{array}$} & \multirow{3}{*}{36} & \multirow{3}{*}{$5.82 \pm 2.46$} & \multirow{3}{*}{1.27} & \multirow{3}{*}{13.24} & \multirow{3}{*}{5.35} & TBL-TMC1 & $1 \mathrm{~mm}$ & 12 & $5.50 \pm 3.19$ & 1.27 & 13.24 & 4.41 \\
\hline & & & & & & & TBL-TMC2 $_{\text {M }}$ & $2 \mathrm{~mm}$ & 12 & $5.98 \pm 2.14$ & 2.65 & 9.63 & 5.88 \\
\hline & & & & & & & ТвL-Тмсз & $3 \mathrm{~mm}$ & 12 & $5.98 \pm 2.08$ & 2.71 & 10.03 & 5.99 \\
\hline & \multirow{6}{*}{$\begin{array}{l}\text { Zr2 } \\
\text { Zirconia veneered with pink ceramic } \\
\text { (e.max ZirCAD MO, Ivoclar Vivadent, } \\
\text { Schaan, Liechtenstein / Creation G2 dark } \\
\text { pink; Creation, Meiningen, Austria) } \\
\text { Zr3 } \\
\text { Zirconia (Atlantis shade 020, Dentstply } \\
\text { International Inc.; New York/New York, } \\
\text { USA) }\end{array}$} & \multirow{3}{*}{36} & \multirow{3}{*}{$7.78 \pm 4.36$} & \multirow{3}{*}{1.65} & \multirow{3}{*}{21.56} & \multirow{3}{*}{7.47} & TBL-TMC1 & $1 \mathrm{~mm}$ & 12 & $10.39 \pm 5.85$ & 2.88 & 21.56 & 8.13 \\
\hline & & & & & & & $\mathrm{T}_{\mathrm{BL}-\mathrm{T}_{\mathrm{MC} 2}}$ & $2 \mathrm{~mm}$ & 12 & $7.12 \pm 2.31$ & 2.38 & 10.38 & 7.24 \\
\hline & & & & & & & 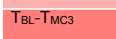 & $3 \mathrm{~mm}$ & 12 & $5.83 \pm 2.95$ & 1.65 & 9.85 & 6.99 \\
\hline & & \multirow{3}{*}{36} & \multirow{3}{*}{$4.73 \pm 2.36$} & \multirow{3}{*}{1.52} & \multirow{3}{*}{12.50} & \multirow{3}{*}{4.19} & TBL-TMC1 & $1 \mathrm{~mm}$ & 12 & $4.30 \pm 1.85$ & 2.80 & 8.92 & 3.34 \\
\hline & & & & & & & $\mathrm{T}_{\mathrm{BL}}-\mathrm{T}_{\mathrm{MC2}}$ & $2 \mathrm{~mm}$ & 12 & $4.95 \pm 2.41$ & 1.60 & 9.46 & 4.97 \\
\hline & & & & & & & TвL-TMC3 & $3 \mathrm{~mm}$ & 12 & $4.93 \pm 2.85$ & 1.52 & 12.50 & 4.93 \\
\hline & \multirow{3}{*}{$\begin{array}{l}\text { Zr4 } \\
\text { Fluorescent zirconia (LAVA Plus High } \\
\text { Translucency Zirconia, Lava Plus Effect } \\
\text { Shade "Fluorescence", 3M ESPE; St. Paul/ } \\
\text { Minnesota, USA) }\end{array}$} & \multirow{3}{*}{36} & & & & & $\mathrm{~T}_{\mathrm{BL}-\mathrm{T}_{\mathrm{MC}}}$ & $1 \mathrm{~mm}$ & 12 & $3.77 \pm 1.88$ & 1.50 & 7.75 & 3.15 \\
\hline & & & $4.33 \pm 2.44$ & 1.50 & 13.80 & 3.80 & TвL-TMC2 & $2 \mathrm{~mm}$ & 12 & $4.09 \pm 2.21$ & 1.90 & 8.58 & 3.39 \\
\hline & & & & & & & $\mathrm{TBL}_{\mathrm{BL}} \mathrm{T}_{\mathrm{MC}}$ & $3 \mathrm{~mm}$ & 12 & $5.12 \pm 3.06$ & 2.36 & 13.80 & 4.72 \\
\hline & & & & & & & $\mathrm{T}_{\mathrm{BL}-} \mathrm{T}_{\mathrm{MC1}}$ & $1 \mathrm{~mm}$ & 12 & $3.78 \pm 2.16$ & 1.47 & 7.99 & 3.20 \\
\hline & $\begin{array}{l}\text { Zirconia (Katana Noritake multilayered; } \\
\text { Kuraray Europe } \mathrm{Gmb} \text {, Hattersheim am }\end{array}$ & 36 & $4.80 \pm 2.51$ & 1.15 & 10.25 & 4.76 & TвL-ТмС2 & $2 \mathrm{~mm}$ & 12 & $5.50 \pm 2.97$ & 1.15 & 10.25 & 5.33 \\
\hline & Main, Germany) & & & & & & $\mathrm{T}_{\mathrm{BL}}-\mathrm{T}_{\mathrm{MC}}$ & $3 \mathrm{~mm}$ & 12 & $5.13 \pm 2.18$ & 2.06 & 8.50 & 5.24 \\
\hline & Ins zirconia Metoxit HTL. & & & & & & $\mathrm{T}_{\mathrm{BL}-\mathrm{T}_{\mathrm{MC1}}}$ & $1 \mathrm{~mm}$ & 12 & $4.29 \pm 2.43$ & 1.53 & 9.84 & 3.60 \\
\hline & Metoxit; Thayngen, Switzerland) & 36 & $5.06 \pm 2.66$ & 0.89 & 14.03 & 4.69 & ТвL-TмС2 & $2 \mathrm{~mm}$ & 12 & $5.58 \pm 3.47$ & 0.89 & 14.03 & 5.29 \\
\hline & & & & & & & $\mathrm{T}_{\mathrm{BL}}-\mathrm{T}_{\mathrm{MC}}$ & $3 \mathrm{~mm}$ & 12 & $5.31 \pm 1.90$ & 2.86 & 8.50 & 4.69 \\
\hline & & & & & & & TBL-TMC1 & $1 \mathrm{~mm}$ & 12 & $7.12 \pm 3.42$ & 1.41 & 13.76 & 6.28 \\
\hline & $\begin{array}{l}\text { Low translucent zirconia (Metoxit TL; } \\
\text { Metoxit; Thayngen, Switzerland) }\end{array}$ & 36 & $6.43 \pm 2.77$ & 1.41 & 13.76 & 6.25 & TBL-TMC2 & $2 \mathrm{~mm}$ & 12 & $6.05 \pm 2.60$ & 1.44 & 10.16 & 5.65 \\
\hline & & & & & & & ТвL-ТМсз & $3 \mathrm{~mm}$ & 12 & $6.11 \pm 2.29$ & 2.30 & 9.14 & 6.34 \\
\hline & Zr8 & & & & & & ТвL-TMC1 $_{\text {ML }}$ & $1 \mathrm{~mm}$ & 12 & $3.56 \pm 2.10$ & 0.94 & 6.88 & 2.97 \\
\hline & Metoxit; Thayngen, Switzerland) & 36 & $4.41 \pm 2.61$ & 0.94 & 12.77 & 4.12 & $\mathrm{~T}_{\mathrm{BL}-\mathrm{T}_{\mathrm{MC2}}}$ & $2 \mathrm{~mm}$ & 12 & $4.50 \pm 2.83$ & 1.44 & 9.35 & 3.62 \\
\hline & & & & & & & ТвL-ТмСз & $3 \mathrm{~mm}$ & 12 & $5.16 \pm 2.79$ & 2.24 & 12.77 & 4.31 \\
\hline & Gol & & & & & & TBL-TMC1 & $1 \mathrm{~mm}$ & 12 & $3.79 \pm 1.84$ & 1.55 & 6.97 & 3.21 \\
\hline & Métaux, Biel, Switerzland) & 36 & $4.59 \pm 2.37$ & 1.30 & 10.23 & 4.20 & ТвL-TмС2 & $2 \mathrm{~mm}$ & 12 & $5.16 \pm 2.63$ & 1.41 & 10.23 & 5.27 \\
\hline & & & & & & & ТвL-ТмСз & $3 \mathrm{~mm}$ & 12 & $4.83 \pm 2.52$ & 1.30 & 8.47 & 5.11 \\
\hline & & & & & & & Тв--ТмС1 & $1 \mathrm{~mm}$ & 12 & $13.99 \pm 6.41$ & 3.42 & 23.96 & 13.56 \\
\hline & Switzerland) & 36 & $7.68 \pm 6.36$ & 0.85 & 23.96 & 5.47 & ТвL-TMC2 & $2 \mathrm{~mm}$ & 12 & $4.87 \pm 3.39$ & 0.93 & 13.76 & 4.00 \\
\hline metal- & & & & & & & ТвL-ТмСз & $3 \mathrm{~mm}$ & 12 & $4.19 \pm 3.32$ & 0.85 & 11.37 & 3.11 \\
\hline based & $\mathrm{Ti2}$ & & & & & & TBL-TMC1 & $1 \mathrm{~mm}$ & 12 & $12.04 \pm 5.45$ & 3.08 & 22.97 & 13.07 \\
\hline & Dental Implants; Baar, Switzerland) & 36 & $7.35 \pm 5.24$ & 1.53 & 22.97 & 5.55 & ТвL-ТмС2 & $2 \mathrm{~mm}$ & 12 & $5.65 \pm 3.84$ & 2.33 & 15.64 & 5.01 \\
\hline & & & & & & & ТвL-ТМсз & $3 \mathrm{~mm}$ & 12 & $4.37 \pm 2.44$ & 1.53 & 9.95 & 3.96 \\
\hline & $\begin{array}{lll}\text { Ti3 } \\
\text { Anodized }(n)\end{array}$ & & & & & & TвL-TMC1 & $1 \mathrm{~mm}$ & 12 & $8.45 \pm 3.17$ & 3.73 & 14.58 & 7.35 \\
\hline & Dental Implants; Baar, Switzerland) & 36 & $6.10 \pm 3.29$ & 0.78 & 14.58 & 5.82 & $\mathrm{~T}_{\mathrm{BL}}-\mathrm{T}_{\mathrm{MC2}}$ & $2 \mathrm{~mm}$ & 12 & $5.03 \pm 3.04$ & 1.05 & 12.92 & 5.02 \\
\hline & & & & & & & Тв--Тмсз & $3 \mathrm{~mm}$ & 12 & $4.82 \pm 2.46$ & 0.78 & 10.50 & 4.66 \\
\hline
\end{tabular}

$\mathrm{n}=$ number of measurements; $\mathrm{SD}=$ standard deviation; $\mathrm{T}_{\mathrm{BL}}=$ spectrophotometric baseline measurement timepoint after flap door preparation without underlying material; $\mathrm{T}_{\mathrm{MC} 1}=$ spectrophotometric measurement timepoint with $1 \mathrm{~mm}$ thick mucosal overlying the test material; $\mathrm{T}_{\mathrm{MC} 2}=$ spectrophotometric measurement time-point with $2 \mathrm{~mm}$ thick mucosal overlying the test material; $\mathrm{T}_{\mathrm{MC} 3}=$ spectrophotometric measurement time-point with 3 $\mathrm{mm}$ thick mucosal overlying the test material 


\section{Figures}

Figure 1 - Pictures and list of all tested materials (manufacturer in brackets).

\section{Material}

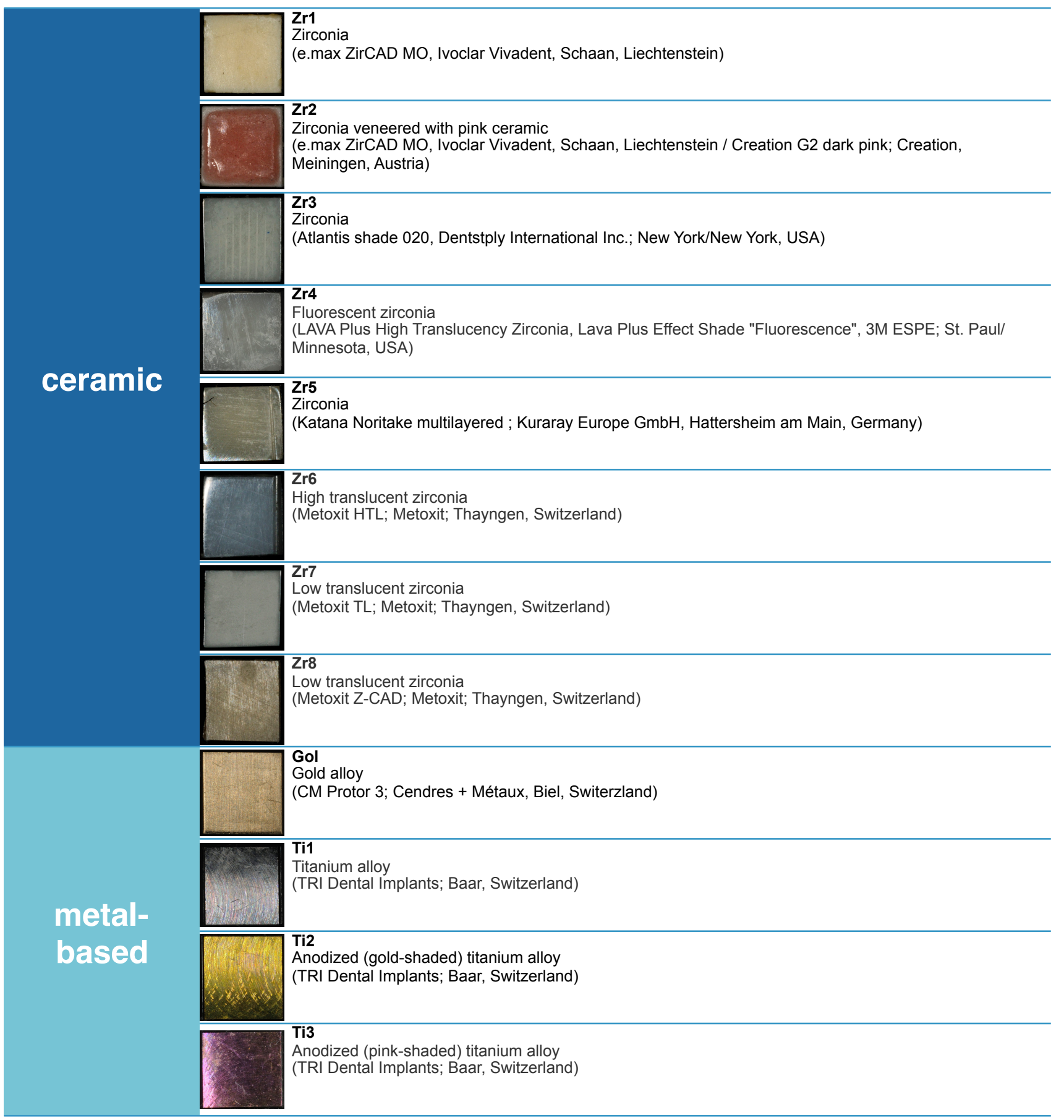


Figure 2 - Surgical protocol and time-points of spectrophotometric measurements.

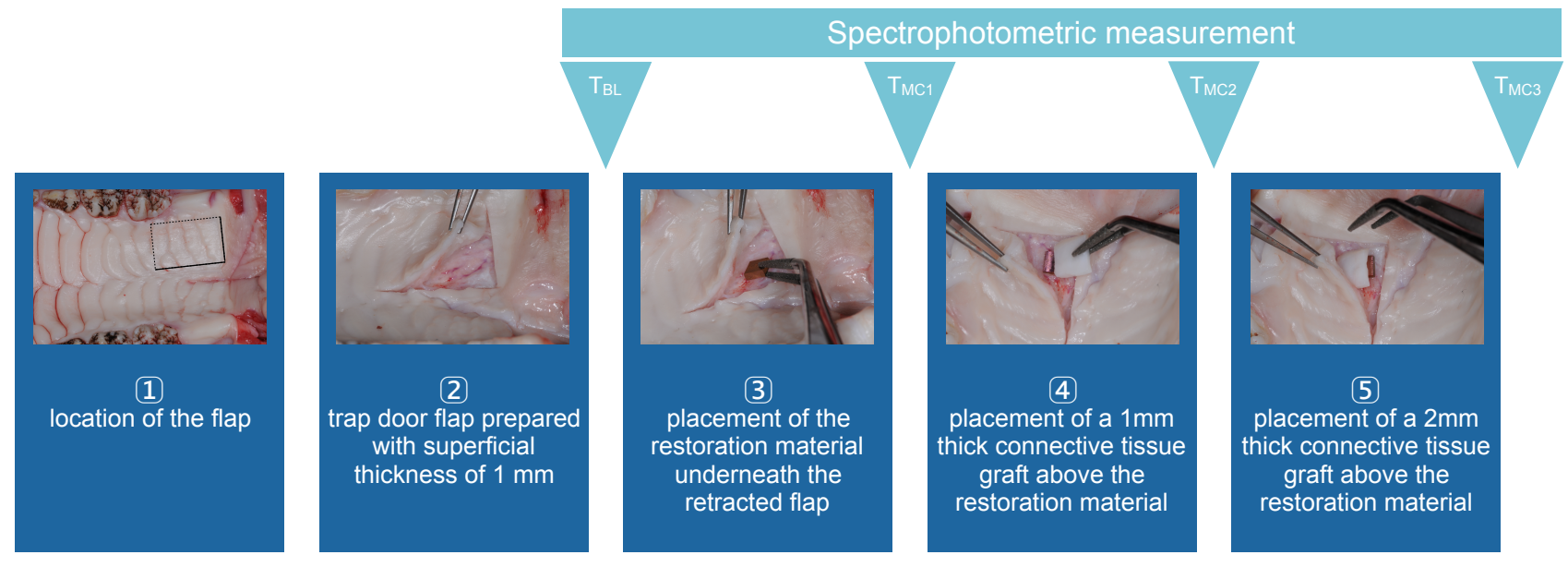

$\mathrm{T}_{\mathrm{BL}}=$ spectrophotometric baseline measurement time-point after flap door preparation without underlying material; $\mathrm{T}_{\mathrm{MC} 1}=$ spectrophotometric measurement time-point with $1 \mathrm{~mm}$ thick mucosal overlying the test material; $\mathrm{T}_{\mathrm{MC} 2}=$ spectrophotometric measurement time-point with $2 \mathrm{~mm}$ thick mucosal overlying the test material; $\mathrm{T}_{\mathrm{MC} 3}=$ spectrophotometric measurement time-point with $3 \mathrm{~mm}$ thick mucosal overlying the test material 


\section{Figure Legends}

Figure 1 - Pictures and list of all tested materials (manufacturer in brackets).

Figure 2 - Surgical protocol and time-points of spectrophotometric measurements. 


\section{References}

Bressan, E., Paniz, G., Lops, D., Corazza, B., Romeo, E. \& Favero, G. (2011) Influence of abutment material on the gingival color of implant-supported all-ceramic restorations: A prospective multicenter study. Clinical Oral Implants Research 22: 631-637.

Cho, K. H., Yu, S. K., Lee, M. H., Lee, D. S. \& Kim, H. J. (2013) Histological assessment of the palatal mucosa and greater palatine artery with reference to subepithelial connective tissue grafting. Anat Cell Biol 46: 171-176.

Claffey, N. \& Shanley, D. (1986) Relationship of gingival thickness and bleeding to loss of probing attachment in shallow sites following nonsurgical periodontal therapy. Journal of Clinical Periodontology 13: 654-657.

Da Silva, J. D., Park, S. E., Weber, H. P. \& Ishikawa-Nagai, S. (2008) Clinical performance of a newly developed spectrophotometric system on tooth color reproduction. Journal of Prosthetic Dentistry 99: 361-368.

Fehmer, V., Muhlemann, S., Hammerle, C. H. \& Sailer, I. (2014) Criteria for the selection of restoration materials. Quintessence International 45: 723-730.

Happe, A., Schulte-Mattler, V., Fickl, S., Naumann, M., Zoller, J. E. \& Rothamel, D. (2013a) Spectrophotometric assessment of peri-implant mucosa after restoration with zirconia abutments veneered with fluorescent ceramic: A controlled, retrospective clinical study. Clinical Oral Implants Research 24 Suppl A100: 28-33.

Happe, A., Schulte-Mattler, V., Strassert, C., Naumann, M., Stimmelmayr, M., Zoller, J. E. \& Rothamel, D. (2013b) In vitro color changes of soft tissues caused by dyed fluorescent zirconia and nondyed, nonfluorescent zirconia in thin mucosa. International Journal of Periodontics and Restorative Dentistry 33: e1-8.

Heydecke, G., Kohal, R. \& Glaser, R. (1999) Optimal esthetics in single-tooth replacement with the re-implant system: A case report. The International Journal of Prosthodontics 12: 184-189. 
Jung, R. E., Holderegger, C., Sailer, I., Khraisat, A., Suter, A. \& Hammerle, C. H. (2008) The effect of all-ceramic and porcelain-fused-to-metal restorations on marginal peri-implant soft tissue color: A randomized controlled clinical trial. International Journal of Periodontics and Restorative Dentistry 28: 357-365.

Jung, R. E., Hurzeler, M. B., Thoma, D. S., Khraisat, A. \& Hammerle, C. H. (2011) Local tolerance and efficiency of two prototype collagen matrices to increase the width of keratinized tissue. Journal of Clinical Periodontology 38: 173-179.

Jung, R. E., Sailer, I., Hammerle, C. H., Attin, T. \& Schmidlin, P. (2007) In vitro color changes of soft tissues caused by restorative materials. International Journal of Periodontics and Restorative Dentistry 27: 251-257.

Kim, A., Campbell, S. D., Viana, M. A. \& Knoernschild, K. L. (2015) Abutment material effect on periimplant soft tissue color and perceived esthetics. Journal of Prosthodontics.

Linkevicius, T. \& Vaitelis, J. (2015) The effect of zirconia or titanium as abutment material on soft peri-implant tissues: A systematic review and meta-analysis. Clinical Oral Implants Research 26 Suppl 11: 139-147.

Paul, S., Peter, A., Pietrobon, N. \& Hammerle, C. H. (2002) Visual and spectrophotometric shade analysis of human teeth. Journal of Dental Research 81: 578-582.

Pecnik, C. M., Roos, M., Muff, D., Spolenak, R. \& Sailer, I. (2015) In vitro color evaluation of esthetic coatings for metallic dental implants and implant prosthetic appliances. Clinical Oral Implants Research 26: 563-571.

Sailer, I., Fehmer, V., Ioannidis, A., Hammerle, C. H. \& Thoma, D. S. (2014) Threshold value for the perception of color changes of human gingiva. International Journal of Periodontics and Restorative Dentistry 34: 757-762.

Sumi, T., Takeshita, K., Takeichi, T., Coelho, P. G. \& Jimbo, R. (2014) Patient-specific gingivacolored abutments: A case series. International Journal of Periodontics and Restorative Dentistry 34: 469-475. 
Thoma, D. S., Ioannidis, A., Cathomen, E., Hammerle, C. H., Husler, J. \& Jung, R. E. (2016) Discoloration of the peri-implant mucosa caused by zirconia and titanium implants. International Journal of Periodontics and Restorative Dentistry 36: 39-45. 